DOI https://doi.org/10.36059/978-966-397-240-4-9

\author{
Мельник О. В. \\ кандидат сільськогосподарських наук, \\ старший науковий співробітник, \\ завідувач лабораторією адаптивного овочівнищтва, \\ зберігання і стандартизації \\ Інститут овочівництва і баштанництва \\ Національної академії аграрних наук України \\ сел. Селекційне, Харківська область

\section{ВИКОРИСТАННЯ АНТИВІРУСНИХ РЕЧОВИН В ОВОЧІВНИЦТВІ І КАРТОПЛЯРСТВІ}

Анотація. Обгрунтовано необхідність стримування виродження сільськогосподарських рослин, що розмножують вегетативним шляхом (зокрема - картоплі і часнику). Встановлено інтенсивність реінфекції оздоровленого насіннєвого матеріалу при послідовному репродукуванні вірусами. Визначено препарати, які мають стримуючий вплив на розвиток вірусів в межах їх прояву. Дослідження препаратів Інтерферон, ДГ-67 та суміші Бровадезу 20 з ДМСО здійснювалось за послідовного накладання обробок та у післядії. Досягнуто зменшення прояву візуальних симптомів вірусних хвороб, що підтверджується даними серологічного аналізу. Ефект від каскадного методу застосування антивірусних препаратів полягає у зростанні продуктивності досліджуваних рослин. Збільшення насіннєвої продуктивності сприяє підвищенню коефіцієнту розмноження. Економічна ефективність розроблених способів підтверджується їх високою рентабельністю та зниженням собівартості продукції.

\title{
Вступ
}

Явище реінфекції насіннєвого матеріалу картоплі, оздоровленого методом апікальних меристем, обумовлює суттєве зменшення урожайності вже перших польових репродукцій. У зонах сильного та помірного виродження поєднання цього фактору з високим природним інфекційним фоном і великою чисельністю переносників вірусів картоплі значною мірою сприяє повторному ураженню оздоровленого насіннєвого матеріалу вірусами у польових 
умовах. За відсутності сортів картоплі з комплексною стійкістю до вірусних хвороб перешкодити масовому перезараженню можливо лише технологічними прийомами (просторова ізоляція, захист від комах-переносників, фітосанітарні прочистки).

Неможливість повного позбавлення рослин картоплі від вірусної інфекції обумовлює пошук методів стримування росту ії концентрації у межах мінімального прояву. Існуючі активні методи елімінації найбільш шкодочинних збудників вірусних хвороб базуються на використанні термо- та хемотерапії в культурі меристем чи вакцинації картоплі слабопатогенними штамами вірусів.

Метою досліджень було створення за допомогою антивірусних препаратів ефективних способів підтримання якості оздоровленого біотехнологічним методом насіннєвого матеріалу в процесі продукування. Для її досягнення були вирішені наступні завдання:

1) вивчено вплив досліджуваних препаратів на ураженість рослин картоплі вірусами X, S, Ү в прихованому стані;

2) вивчено візуальний прояв вірусних хвороб під впливом досліджуваних препаратів;

3) встановлено характер змін у продуктивних показниках насіннєвої картоплі під дією вказаних препаратів;

4) досліджено інтенсивність процесу виродження оздоровленої картоплі при використанні речовин антигенної природи.

Наукова новизна даних досліджень полягає у встановленні впливу речовин антигенної природи на накопичення та прояв вірусів в оздоровленому насіннєвому матеріалі картоплі.

Практичне значення розроблених способів полягає у суттєвому зменшенні втрат від ураження посівів вірусними хворобами, зростанні урожайності та насіннєвої продуктивності картоплі, що підтверджується відповідним зростанням економічної ефективності. Також велике значення має економія ресурсів при проведенні фітосанітарних прочисток, отриманого з використанням розроблених способів насіннєвого матеріалу.

\section{1. Стан вивчення питання}

Однією з основних проблем насінництва картоплі $є$ так зване виродження (дегенерація) культури: 3 кожною новою репродукцією рослин знижується їх продуктивність, змінюються морфологічні та фізіолого-біохімічні показники. Швидкість та ступінь погіршення продуктивних якостей залежить, перш за все, від грунтово-кліматичних умов зони вирощування, і особливо від 
розповсюдження в них вірусних хвороб, кільцевої та сухої гнилизни, чорної ніжки, фітофторозу та ін. [1-3].

Існують теорії, які по-різному пояснюють причини виродження картоплі (екологічна, температурна, вірусна, імунна, генетична, теорія токсинів та фізіологічного старіння) і передбачають різні шляхи боротьби $з$ ними $[4 ; 5]$. Однією з перших наукових теорій виродження картоплі пояснювалось його фізіологічним старінням внаслідок тривалого вегетативного розмноження (Пермантьє, 1786; Г.М. Лінник, 1955, 1957; А. Герн, 1961; П.А. Генкель, 1963). У відповідності з цим вважалось, що виродження картоплі - це зовнішній прояв ії старіння і $\epsilon$ закономірним процесом вікової мінливості, що закладено в самій природі рослини. А вірус не причина, а лише наслідок виродження, старіння сорту [6]. Виходячи 3 цього, було запропоновано скошувати бадилля на весняних посівах і таким способом переносити утворення бульб на осінній період, а також отримувати нові сорти шляхом висіву ботанічного насіння, яке утворюється в ягодах рослин [7]. Ця теорія була домінуючою протягом тривалого часу і продовжує вдосконалюватися в теперішній час $[2 ; 3 ; 8]$.

Теорія екологічної депресії пояснює виродження несприятливими екологічними факторами, домінуючим з яких $є$ температура, i недосконалістю прийомів вирощування та зберігання бульб (Г. Морштатт, 1925; Ф. Меркеншлягер, 1929-1932; Циглер, 1932; Т.Д. Лисенко, 1947; О.М. Фаворов, 1965; Л.В. Рожалін, 1966). Різними вченими виродження картоплі, зокрема розвиток зморшкуватої мозаїки, готики, скручування листя та інших, вважалось порушенням співвідношення між вуглеводами та азотистими речовинами або порушенням водного балансу і перенасиченням рослин солями внаслідок високої коллоїдності і вмісту калію в грунті $[2 ; 3 ; 9 ; 10 ; 11]$. Екологічна теорія заходи боротьби з виродженням зводить до вирощування картоплі в районах, найбільш відповідних біологічним особливостям культури, збалансованому внесенню добрив, пізній посадці, правильному зберіганню бульб і т.д. $[12 ; 13 ; 14 ; 15 ; 16 ; 17]$. Теорія екологічного виродження сприяла розробці різних технологічних і насінницьких прийомів, обумовлюючих ріст урожайності в більшості країн.

Теорія токсинів (А.С. Сабашников, 1936; М.Г. Бондарєв, 1938; С.П. Орлов, 1940; М.М. Муш, 1959) пояснює виродження картоплі дією токсичних речовин материнської бульби, які нагромаджуються при несприятливих температурних умовах. Для запобігання 
шкідливої дії токсинів на рослини пропонується висаджувати картоплю невеликими шматочками бульб або відокремленими від них паростками [18; 19].

На сьогодні домінуючою $є$ вірусна теорія. Згідно з цією теорією виродження $є$ патологічним явищем, яке відбувається під дією вірусів та вірусоподібних організмів [20-27]. В теперішній час відомо вже більше 30 таких збудників, вражаючих картоплю [28; 29].

Багаті вуглеводами та водою картоплиння і бульби є сприятливим середовищем для розвитку патогенів, зокрема вірусів. Вегетативне ж розмноження картоплі забезпечує можливість їх існування в активному стані протягом тривалого часу в період вегетації у рослинах і бульбах, а в період зберігання - у бульбах.

Вірусологи вважають, що на перебіг вірусних хвороб картоплі дуже впливають екологічні фактори. Негативний вплив їх виявляється не тільки в безпосередньому погіршенні насінних якостей бульб, але і в зниженні опору рослин проти вірусних хвороб.

Уражений вірусами організм рослини активно бореться із захворюванням. Результат цієї боротьби залежить не тільки від внутрішніх факторів, що зумовлюють імунітет рослин, але й від різних факторів зовнішнього середовища [30-40].

Основними заходами захисту є селекція вірусостійких сортів і оздоровлення насіннєвого матеріалу методом культури тканин 3 послідуючим культивуванням в умовах ефективного захисту від вторинної інфекції [41].

Нещодавно з'явилася гіпотеза, яка пояснює виродження картоплі 3 позицій імунітету рослин [41]. Перспективним $\epsilon$ пояснення виродження $з$ позицій генетики, при якому особлива увага приділяється необхідності диференційованого підходу до оздоровлення кожного конкретного сорту від кожного конкретного вірусу [42; 43].

У літературі зустрічаються різні дані відносно шкодочинності вірусних хвороб залежно від видів та штамів вірусів. Найбільш значущий вплив на симптоми вірусних хвороб мають віруси $L, X, S$, M, Y, A, F, R.

Віруси складаються з білкових молекул і нуклеїнових кислот. Вони не мають власного обміну речовин, у них відсутні типові клітинні органели, вони розмножуються тільки в організмі господаря чи переносника, на штучних поживних середовищах не ростуть, мають своєрідний механізм розмноження, в їх складі немає води [44]. 
Більшість фітопатогенних вірусів можна віднести до чотирьох морфологічних груп: палочкоподібні, ниткоподібні, сферичні, бацилоподібні. Віруси картоплі мають, переважно, ниткоподібну форму (X, M, Y).

Генетичний апарат вірусів представлений всіма можливими формами нуклеїнових кислот : одно - і двухнитчастою РНК, одно - i двухнитчастою ДНК. Білкова оболонка вірусу - капсида складається з двох типів білкових молекул - гемаглютининів (з їх допомогою вірус кріпиться до клітинної оболонки) і нейрамінідаз, які блокують захисні властивості клітинних мембран, коли вірусу необхідно потрапити в клітину чи вийти з неї [45].

Клітини організму при контакті з вірусом продукують специфічні антитіла проти його гемаглютининів і нейрамінідаз, що робить можливою ідентифікацію вірусів серологічними методами [44].

Відмінна особливість розмноження вірусів полягає в тому, що в клітину потрапляє лише їх нуклеїнова кислота. Синтез білкового і нуклеїнового компонентів у часі та просторово рознесений і відбувається за рахунок матеріалу і енергії клітини-господаря, після чого відбувається формування нових вірусних часток [2; 44; 46].

Для вірусів характерна наявність позаклітинної інфекційної фази (віріонів), що забезпечує їх незалежне існування. Більшість виділених з клітин вірусів утворюють кристалічні скупчення характерної для кожного з них форми і розміру. У такому бездіяльному віріонному стані віруси можуть перебувати досить довго, не втрачаючи здатності ушкоджувати живі клітини організму.

На відміну від вірусів, віроїди не мають білкової оболонки і складаються лише з ковалентно замкнутої кільцевої РНК, маючої порівняно невисоку молекулярну масу [44]. Віроїди внаслідок біологічних особливостей здатні тривалий час зберігатися у воді та поживних розчинах 3 широким діапазоном $\mathrm{pH}$ i залишатися інфекційними при $100{ }^{\circ} \mathrm{C}$ [47].

Для віроїду веретеноподібності бульб картоплі відомий ряд штамів, які різняться за ступенем вираження патологічних ознак, які вони викликають у рослини-господаря. Визначення нуклеотидної послідовності свідчить про те, що ці штами різняться лише 3-4 нуклеотидними замінами [48].

Деякі хвороби виродження картоплі (стовбурне в'янення, пурпурне скручування верхівки, відьмині мітли, пожовтіння) викликані мікоплазмами [2]. Мікоплазми представлені групою поліморфних організмів, які не мають справжньої клітинної стінки, що істотно відрізняє їх 
від бактерій. На відміну від вірусів вони мають клітинну будову і здатні розмножуватися на штучних поживних середовищах [44].

Фітопатогенні віруси самостійно у природі поширюватися не можуть. Вони переносяться різними комахами, грибами, контактно при стиканні хворих і здорових рослин, сільськогосподарськими машинами і знаряддями, людиною, бульбами тощо [29].

Віруси, що проникли у рослину, переміщуються в бульби, де й нагромаджуються, знижуючи 3 кожним роком урожайність картоплі [49; 50]. Патогени викликають хвороби, які призводять до зміни фізіологічних процесів - дихання, фотосинтезу, утворення амінокислот, білків, вуглеводів, нуклеїнових кислот, вітамінів та багатьох інших речовин [51-55].

Для різних хвороб характерні різні патологічні зміни. Так, інфекціям мозаїчного типу властиве руйнування хлорофілу в паренхімі листків і ростова деформація; при скручуванні листя і мікоплазмозах спостерігається ураження провідної системи закупорення і некроз судин. В уражених рослинах, як правило, посилюється транспірація, знижується вбирна здатність коріння. Внаслідок цих змін рослини втрачають здатність ефективно використовувати вологу і мінеральне живлення.

Залежно від способу перенесення вірусів, останні можна розподілити на облігатно-ентомофільні, які переносяться комахами, зокрема попелицями та цикадками (L, вірус жовтої карликовості); контактно-векторні, які переносяться як переносником (комахи, нематоди, грунтові гриби),так і механічно-контактним шляхом (Y, A, M, F, R, вірус щіткоподібності верхівки, вірус мозаїки люцерни); контактні віруси, які переносяться переважно механічно (S, X).

Однією з особливостей вірусів $є$ їхня здатність вражати організм господаря без прояву симптомів захворювання. Відрізняють латентну і приховану форми зараження.

У латентній формі вірус можна виявити, користуючись сучасними способами діагностики: він зберігає інфекційність і, заражуючи інші рослини, здатний викликати в них симптоми захворювання. У прихованому стані вірусні частки в організмі виявити не вдається. Вони неінфекційні і перебувають в особливому фізичному стані. Їхня інфекційність може проявитися лише після дії певного провокуючого фактору [56].

Віруси в латентній формі менш шкодочинні, ніж у відкритій. Та ж різниця має місце між слабкими і сильними штамами одного й того ж вірусу. 
Шкодочинність вірусної інфекції в результаті проявляється в зменшенні у гнізді хворої рослини кількості і розміру бульб. Зменшення урожайності картоплі при садінні ураженими найбільш поширеними вірусами бульбами складає : У - 20-90\%, L - 28-64, M (K) - 9-48, X - 10-28, R - 10-30, S - 10-20, A - 10-15, F - до $10 \%$; віроїдом веретеноподібності бульб - 20-85 \%; мікоплазмами - до $10 \%[2 ; 3 ; 57]$.

Нерідко на одній рослині можуть бути наявні ознаки двох і більше вірусних захворювань. Віруси, які викликають лише незначне зниження врожайності (легкі вірусні захворювання),такі, як S, X, A при змішаній інфекції з іншими вірусами (L, Y) у результаті ефекту синергізму можуть значно підвищувати свою шкодочинність і різко знижувати врожайність бульб. У цих випадках уражені рослини мають симптоми тяжких форм вірозів і знижують урожайність до $50 \%$ і більше $[2 ; 3 ; 29 ; 40 ; 58 ; 59]$. Кожен відсоток ураження садивного матеріалу вірусами знижує урожайність картоплі на 0,5 \% [60].

Використання вихідного оздоровленого біотехнологічними методами матеріалу забезпечує приріст урожаю бульб на 12-75\% залежно від сорту і якості насіннєвого матеріалу [60-62]. У зв'язку з цим виділилася самостійна галузь насінництва - виробництво насіннєвого матеріалу шляхом використання активних методів оздоровлення через культуру тканин (апікальну меристему), термо- та хіміотерапію вірусів. В Україні 70 \% всієї еліти картоплі виробляється на оздоровленій (безвірусній) основі $[61 ; 63]$.

Проте, разом з тим використання згаданих методів має істотні недоліки. По-перше, через відсутність 100 \%-вої діагностики важко стверджувати, що отримані рослини in vitro $\epsilon$ вільними від вірусів. По-друге, відомі факти утворення термостійких вірусів, що зводить нанівець використання методу термотерапії. По-третє, при певних умовах гени вірусів вмонтовуються в геном рослини, а тому стають недосяжними. Тобто, метод термотерапії та верхівкової меристеми не дає гарантії отримання рослин, вільних від вірусної інфекції [59].

Саме поняття „безвірусна картопля» досить відносне. В даному випадку мова йде тільки про небагато поширених вірусів, які порівняно просто визначаються в латентному стані методом серодіагностики. Але при цьому не виключається наявність прихованої чи слабо вираженої інфекції, яку не вдається визначити в рослині існуючими методами.

При розмноженні насіннєвої картоплі, оздоровленої як шляхом добору здорових рослин з додатковою перевіркою на приховане 
ураження вірусами (клоновий добір),так і вирощених з верхівкової меристеми, трапляються рецидиви вірусної інфекції, не пов'язані 3 повторним ураженням нею [64].

У зв'язку з цим можна зробити припущення, що в процесі оздоровлення не відбувається повного звільнення від вірусу, а проходить елімінація його активної форми чи зниження концентрації вірусного антигену до рівня, нижчого за межу чутливості методів діагностики. Але і в цьому разі оздоровлення виконує позитивну функцію: якщо не в абсолютному звільненні від вірусів, то в захисті від вірусних хвороб, знижуючи і стримуючи розвиток вірусів до рівня їх прояву і шкодочинності [61].

У той же час слід розрізняти поняття «віруси» та „вірусні хвороби». Існує припущення, що віруси - лише потенційні збудники хвороб, а хвороби $є$ особливою, але не обов'язковою реакцією рослин-господарів, що визначається їх генетичною природою і зовнішніми умовами $[43 ; 65]$.

За даними досліджень НДІ картопляного господарства Росії оздоровлений матеріал вдвічі менше пошкоджувався паршею звичайною i різоктоніозом, був стійкішим проти збудників кільцевої та мокрої гнилі, чорної ніжки [60]. Але оздоровлений насіннєвий матеріал при вирощуванні в полі значною мірою схильний до повторного ураження вірусами через високий інфекційний стан і велику чисельність переносників вірусів картоплі (головним чином - попелиць), а в окремих випадках інтенсивної дії природних факторів на розвиток прихованої вірусної інфекції в оздоровленому матеріалі $[67 ; 68]$.

Насамперед це стосується оздоровленого матеріалу мікробульб або рослин, одержаних у пробірці, коли їх висаджують у поле. Сходи таких рослин внаслідок їх біологічних особливостей тривалий час залишаються фізіологічно молодими і значною мірою схильними до ураження вірусними патогенами. Уже в перший рік внаслідок повторного ураження вірусною інфекцією недобір урожаю становить 13-20\% [69].

Це пояснюється тим, що звільнення від вірусів у процесі оздоровлення їх активними методами 3 використанням мікроклонального розмноження in vitro робить сорт більш чутливим до повторного ураження. У меристемних рослин вірусна інфекція із прихованої форми може масово переходити в явну, особливо при стресовому погіршенні умов вирощування, що різко знижує урожайність насіннєвого матеріалу. 
Деякі дослідники вважають, що повне звільнення картоплі від вірусів сприяє втраті генетично обумовленої толерантності сорту до вірусної інфекції [70]. Тому оздоровлення доцільне лише тоді, коли в полі рослини залишаються поза контактом з вірусною інфекцією. Оскільки це практично неможливо, то вони вважають, що оздоровлення створює тиск штучного добору на збереження популяції нестійких проти вірусів рослин [61; 71; 72].

Оздоровлення рослин картоплі активними методами i ï розмноження внаслідок істотного збільшення мікромутаційної гетерогенності різних господарсько-біологічних ознак та властивостей призводить до біологічного забруднення сортів картоплі у вигляді мікромутаційних генотипових змін кількісних ознак, які зумовлюють продуктивність, зниження стійкості до хвороб та адаптивності, зміни скоростиглості тощо.

Це суттєво зменшує ефективність ведення первинного насінництва картоплі прискореним методом мікроклонального розмноження in vitro, а також погіршує збереження генофонду у вигляді колекцій мікробульб, одержаних від меристемних рослин у пробірках. Тому при веденні первинного насінництва на біотехнологічній основі слід враховувати можливість генетичної гетерогенності меристемного вихідного матеріалу картоплі [72], бо 3 врахуванням значного коефіцієнту розмноження при культивуванні in vitro навіть дуже рідко виникаючі зміни створюють серйозну небезпеку для сортів [44; 73; 74; 75].

Відносно перспективним методом захисту від вірусів та вірусних хвороб $\epsilon$ інокуляція (вакцинація) рослин слабопатогенними штамами $[28 ; 66]$. Хоча, навіть при ураженні рослин слабкими штамами вірусів втрачається 5-10\% урожаю, інфіковані рослини $\epsilon$ потенційним джерелом інфекції, невідомою залишається реакція інших сортів на слабкий штам того чи іншого вірусу і нарешті, існує загроза появи агресивних мутантів [61].

Багато вчених вважає, що одним 3 найбільш перспективних напрямків отримання здорового від вірусних та інших хвороб насіннєвого матеріалу є використання для цих цілей ботанічного насіння. Але цей метод теж має цілу низку невирішених проблем [59].

Певна частина вчених вважає, що клоновими доборами вдається знизити загальний патогенний тиск в посівах картоплі, зокрема насінницьких, і тим самим зменшити втрати врожаю від вірусних хвороб. У той же час необхідно відмітити, що культура меристем і клоновий добір в насінництві мають різні завдання. 
Якщо метод культури тканин передбачає елімінацію вірусної інфекції і зростання коефіцієнту розмноження, то клоновий добір взагалі вилучає із подальшого розмноження генетично малоцінний матеріал і підтримує морфобіологічну типовість сорту [61; 76]. Обидва ці методи повинні доповнювати один одного.

Клоновий добір дає змогу суттєво підвищити ефективність селекції картоплі, особливо на польову вірусостійкість, продуктивність i життєздатність, а іноді й адаптивність, фітофторостійкість, скоростиглість, стійкість проти механічних пошкоджень тощо [70; 77].

Відомо, що різні сорти картоплі по-різному реагують на оздоровлення. Це проявляється в інтенсивності їх повторного ураження вірусною інфекцією та продуктивних якостях [61]. Накопичення вірусної інфекції в рослинах і урожайність картоплі при репродукуванні еліти залежить не стільки від виду насіннєвого матеріалу та способу його отримання, як від генотипу сорту [78; 63].

Одним з дієвих способів запобігання ураження вірусними хворобами $\epsilon$ створення стійких до вірусів сортів. Стійкість більшості з них базується на таких її типах, як польова стійкість та надчутливість. Сортів з комплексною стійкістю до вірусів на даний час не існує [29; 46; 79].

Для захисту насінницьких насаджень від інфікування вірусами і мікоплазмами обов'язковим $\epsilon$ комплекс таких технологічних заходів, як просторова ізоляція насінницьких посівів від посівів іншого призначення; раннє садіння пророщеними бульбами та раннє знищення картоплиння 3 урахуванням нагромадження врожаю та строків масового льоту переносників; збалансоване використання добрив та зрошення; застосування хімічних препаратів для захисту від комах-переносників; боротьба 3 бур'янами як джерелом вірусної інфекції на посадках та навколо них; ретельне проведення фітосанітарних прочисток $[3 ; 44 ; 57$; 80-85].

Суттєво зменшити вірусне навантаження при регенерації рослин in vitro та послідуючому репродукуванні дозволяє використання синтетичних хімічних препаратів. Встановлено антивірусу дію таких речовин, як рибонуклеаза [86], кампозан [87], тур (хлорхолінхлорид), сорбінова кислота, фенольні сполуки, антибіотик іманін [88], перманганат калію [89], віразол [58; 90], препарати ТБ [91], ДГТ (2,4-діоксогексо-1,3,5-триазин) [92], цианогуанідін, натрійалканмоносульфат, 2-аніліно-5-адамантіл-1,3,4-тіадіазол, 
глікозиди (нікотіанозид, сомелонгозид, томатозид, фітонік), 2,5-олігоаденілати та інших органічних і неорганічних сполук [45].

Але в більшості випадків їх використання обмежувалось додаванням до складу живільних середовищ, що не мало довготривалого ефекту при репродукуванні в польових умовах. Тому існує необхідність створення способів стримування реінфекції картоплі впродовж всього процесу виробництва оригінального та елітного насіння.

Препарати, використані у дослідах:

Iнтерферон лейкоцитарний людський сухий (INTERFERONUM LEUCOCYTICUM HUMANUM) відноситья до цитокінів і складається 3 суміші різних підтипів натурального Інтерферону альфа 3 лейкоцитів людини. Механізм противірусної дії полягає в створенні захисних механізмів в неінфікованих вірусом клітинах: зміна властивостей клітинних мембран, що перешкоджають проникненню вірусу в клітину; ініціація синтезу низки специфічних ферментів, що запобігають реплікації вірусної РНК і синтезу білків вірусу. Існують дані про здатність вірусів рослин ініціювати утворення ендогенного Інтерферону в організмі тварин і людини, що може бути доказом спорідненості рослинного та тваринного Інтерферону за походженням та принципом дії.

ДГ-67 (ді-(N-оксид-2-метилпіридин)-цинк (II)-йодид) відноситься до групи піридинів i $\epsilon$ аналогом препарату ДГ-77 (ді-(N-оксид-2-метилпіридин)-цинк (II)-хлорид, який має антивірусні властивості та стимулює ріст та розвиток рослин картоплі (патент України на винахід № 77677 від 15 січня 2007 р.).

Бровадез 20 (діюча речовина - бензалконія хлорид) $\epsilon$ дезінфекатом 3 вираженою бактеріцидною, віруліцидною та фунгіцидною дією, який широко використовується в ветеринарії та медицині. $€$ відомості про його вплив на парамікровіруси, каліцивіруси, рабдовіруси та інш.

Використання препарату ДМСO (DIMETHYLSULFOXIDE, діметисульфоксид, дімексид) зумовлено його здатністю проникати через біологічні мембрани, тому його часто застосовують для посилення дії інших речовин, в даному випадку - Бровадезу 20.

Польові досліди проводили в 2007-2010 pp. в Інституті овочівництва і баштанництва НААН на полях овочевої сівозміни. Інститут знаходиться в східній частині лівобережного Лісостепу України, на території Харківського району. Проведеними дослідженями вивчалась антивірусна дія препаратів Інтерферон, ДГ-67 та суміші Бровадезу 20 з ДМСО. 
Обробка рослин картоплі ранньостиглого сорту Тирас антивірусними препаратами виконувалась по досягненні рослинами висоти 10-15 см через кожні 7 діб шляхом обприскування. Вивчення післядії досліджуваних препаратів на процеси накопичення вірусної інфекції оздоровленої картоплі здійснювалось при подальшому послідовному репродукуванні 3 використанням методу накладання.

Польовий дослід був закладений згідно «Методичних рекомендацій щодо проведення досліджень 3 картоплею» (Немішаєве, 2002): повторність 4-х-разова, ділянки 4-х-рядкові, схема садіння - $70 \times 35$ (густота садіння - 40,8 тис. шт./га), площа

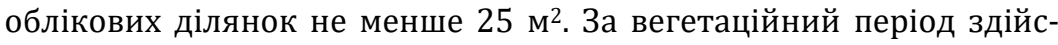
нено 5 обробок рослин розчинами досліджуваних препаратів.

Схема проведення досліджень по роках

\begin{tabular}{|c|c|c|c|c|}
\hline $\begin{array}{l}\text { № } \\
\text { вар. }\end{array}$ & Препарат & $\begin{array}{l}\text { Суперсупереліта } \\
\text { (2007-2009 рр.) }\end{array}$ & $\begin{array}{c}\text { Супереліта } \\
\text { (2008- } \\
2010 \text { рp.) } \\
\end{array}$ & $\begin{array}{c}\text { Еліта* } \\
\text { (2009- } \\
2010 \text { pp.) }\end{array}$ \\
\hline 1 & \multirow{3}{*}{ Інтерферон } & обробка & $\begin{array}{l}\text { накладання } \\
\text { обробок }\end{array}$ & $\begin{array}{l}\text { накладання } \\
\text { обробок }\end{array}$ \\
\hline 2 & & обробка & $\begin{array}{l}\text { накладання } \\
\text { обробок }\end{array}$ & $\begin{array}{l}\text { післядія } \\
\text { накладання }\end{array}$ \\
\hline 3 & & обробка & післядія & $\begin{array}{l}\text { післядія } \\
\text { післядії }\end{array}$ \\
\hline 4 & \multirow{3}{*}{ ДГ-67 } & обробка & $\begin{array}{l}\text { накладання } \\
\text { обробок }\end{array}$ & $\begin{array}{l}\text { накладання } \\
\text { обробок }\end{array}$ \\
\hline 5 & & обробка & $\begin{array}{l}\text { накладання } \\
\text { обробок }\end{array}$ & $\begin{array}{l}\text { післядія } \\
\text { накладання }\end{array}$ \\
\hline 6 & & обробка & післядія & $\begin{array}{l}\text { післядія } \\
\text { післядії }\end{array}$ \\
\hline 7 & \multirow{3}{*}{$\begin{array}{l}\text { Бровадез } 20 \text { + } \\
+ \text { ДМСО }\end{array}$} & обробка & $\begin{array}{l}\text { накладання } \\
\text { обробок }\end{array}$ & $\begin{array}{l}\text { накладання } \\
\text { обробок }\end{array}$ \\
\hline 8 & & обробка & $\begin{array}{l}\text { накладання } \\
\text { обробок }\end{array}$ & $\begin{array}{l}\text { післядія } \\
\text { накладання }\end{array}$ \\
\hline 9 & & обробка & післядія & $\begin{array}{l}\text { післядія } \\
\text { післядії }\end{array}$ \\
\hline 10 & Контроль & \multicolumn{3}{|l|}{ без обробки } \\
\hline
\end{tabular}

*-двохрічні дані 
Визначення антивірусної дії Інтерферону на рослини часнику виконували на сортах Дюшес і Мереф'янський білий. Обробку рослин каскадним методом здійснювали за їх наклдання при послідовному розмноженні садивного матеріалу.

Економічні розрахунки здійснено за відповідними на час проведення досліджень цінами та тарифами.

\section{2. Вплив досліджуваних препаратів}

\section{на розвиток вірусів та прояв вірусних хвороб}

За прийнятим в Україні положенням насіннєвий матеріал картоплі повинен відповідати вимогам ДСТУ 4013-2001 «Сортові та посівні якості картоплі насінної. Технічні умови» (Київ, 2001), згідно якого ураженість посівів картоплі в умовах Лісостепу за зовнішніми ознаками не повинна перевищувати на момент апробації 2,5 \% для оригінального насіння (в т. ч. 0,5 \% - тяжкими вірусними хворобами, ВВБК та мікоплазмами, 2,0\% - легкими вірусними хворобами) та 4,8 \% для елітного насіння (в т. ч. 1,0 \% тяжкими вірусними хворобами, ВВБК та мікоплазмами, 3,5\% легкими вірусними хворобами, 0,3 \% - чорною ніжкою). Зазначений рівень ураженості посівів повинен бути забезпечений своєчасним проведенням фітосанітарних прочисток під час яких рослини 3 симптомами хвороб видаляються з поля.

Отриманий методом культури апікальних меристем оздоровлений насіннєвий матеріал репродукувавася до еліти за чотирьохрічною схемою насінництва. В ході проведених досліджень виконувалось по 2-3 прочистки за вегетаційний період, під час яких виконувався облік ураженості рослин хворобами за візуальними ознаками.

Ураження сорту Тирас відбувалося переважно легкими вірусними хворобами (звичайна та складчаста мозаїка, аукуба-мозаїка), та в незначній мірі (переважно - еліта) - тяжкими вірусними хворобами (зморшкувата мозаїка, скручування та мозаїчне закручування листя) і мікоплазмами. На розвиток вірусних хвороб значний вплив спричинили погодні умови. Особливо складними вони були у 2009 і 2010 роках.

Зменшення ураженості суперсупереліти вірусними хворобами при використанні досліджуваних препаратів порівняно до контролю (2,8 \%) склало 0,7-1,5 \% (табл. 1). Найсуттєвішим воно було при використанні екзогенного Інтерферону - майже в 2,2 рази, що свідчить про інгібування прояву вірусів за його впливу. 
Таблиця 1

\section{Ураженість суперсупереліти картоплі \\ вірусними хворобами за впливу каскадної обробки посівів антивірусними препаратами}

\begin{tabular}{|l|c|c|c|c|}
\hline \multirow{2}{*}{\multicolumn{1}{|c|}{ Препарат }} & \multicolumn{4}{|c|}{ Візуальні симптоми хвороб, \% } \\
\cline { 2 - 5 } & $\mathbf{2 0 0 7}$ & $\mathbf{2 0 0 8}$ & $\mathbf{2 0 0 9}$ & середнє \\
\hline 1. Інтерферон & 2,7 & 1,1 & 0 & $\mathbf{1 , 3}$ \\
\hline 2. ДГ-67 & 3,5 & 2,7 & 0 & $\mathbf{2 , 1}$ \\
\hline 3. Бровадез 20 + ДМСО & 2,4 & 2,5 & 0 & $\mathbf{1 , 6}$ \\
\hline 4. Без обробки (контроль) & 3,9 & 3,9 & 0,7 & $\mathbf{2 , 8}$ \\
\hline
\end{tabular}

Результати серологічного аналізу свідчать про відсутність вірусів X, S та У у рослинах усіх досліджуваних варіантів, тоді як 3,4 \% рослин контрольного варіанту були інфіковані (табл. 2).

Таблиця 2

Ураженість суперсупереліти картоплі вірусами за впливу каскадної обробки посівів антивірусними препаратами

\begin{tabular}{|l|c|c|c|c|}
\hline \multirow{2}{*}{ Препарат } & \multicolumn{3}{|c|}{ Віруси X, S, У в латентній формі, \% } \\
\cline { 2 - 5 } & $\mathbf{2 0 0 7}$ & $\mathbf{2 0 0 8}$ & $\mathbf{2 0 0 9}$ & середнє \\
\hline 1. Інтерферон & 0 & 0 & 0 & $\mathbf{0}$ \\
\hline 2. ДГ-67 & 0 & 0 & 0 & $\mathbf{0}$ \\
\hline 3. Бровадез 20 + ДМСО & 0 & 0 & 0 & $\mathbf{0}$ \\
\hline 4. Без обробки (контроль) & 0 & 5,2 & 5,0 & $\mathbf{3 , 4}$ \\
\hline
\end{tabular}

Процес реінфекції оздоровленого матеріалу розпочався вже 3 другого року вирощування у польових умовах. Ураженість супереліти картоплі вірусними хворобами в контрольному варіанті зросла на $6,5 \%$, тоді як при використанні Інтерферону - лише на 3,5\%, що свідчить про наявність післядії цього препарату (табл. 3). При цьому збільшення симптомів прояву хвороб при використанні ДГ-67 та Бровадезу 20 з ДМСО на 6,4-6,5 \% призвело до менших, ніж у контролі значень.

В латентній формі вірусами (переважно S, рідше - X) при використанні Інтерферону було уражено $1,7 \%$ рослин, Бровадезу 20 з ДМСО - 1,2 \%, у контролі - 5,2 \% (табл. 4).

У випадку, коли використовувалось накладання обробок досліджуваними препаратами, зростання ураженості при застосуванні Інтерферону склало лише 2,8 \%, ДГ-67-4,7, Бровадезу 203 ДМСО - 2,7\%. Віруси в латентній формі спостерігались лише при використанні Бровадезу з ДМСО (1,2%). 
Ознаки ураження еліти картоплі в контрольному варіанті мали $12,0 \%$ рослин (табл. 5). Найпомітнішою післядія була при використанні Інтерферону (9,0\%). При використанні ДГ-67 та Бровадезу 20 з ДМСО симптоми були у 12,2 та $10,5 \%$ рослин, відповідно.

Таблиця 3

Ураженість супереліти картоплі вірусними хворобами за впливу каскадної обробки посівів антивірусними препаратами

\begin{tabular}{|c|c|c|c|c|c|c|c|c|}
\hline \multirow[b]{3}{*}{ Препарат } & \multicolumn{8}{|c|}{ Візуальні симптоми хвороб, \% } \\
\hline & \multicolumn{4}{|c|}{$\begin{array}{l}\text { післядія } \\
\text { обробки }\end{array}$} & \multicolumn{4}{|c|}{$\begin{array}{c}\text { накладання } \\
\text { обробки }\end{array}$} \\
\hline & $\begin{array}{l}\infty \\
\stackrel{ᄋ}{O} \\
\text { ㄱ }\end{array}$ & 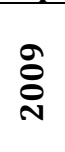 & 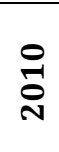 & 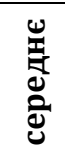 & $\begin{array}{l}\infty \\
\stackrel{\overbrace{}}{0} \\
\text { ㄱ }\end{array}$ & $\begin{array}{l}\text { g̊ } \\
\text { } \\
\text { ○े }\end{array}$ & $\begin{array}{l}\stackrel{0}{2} \\
\stackrel{\text { }}{N}\end{array}$ & 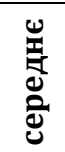 \\
\hline 1. Інтерферон & 6,3 & 3,3 & 4,7 & 4,8 & 5,7 & 2,3 & 4,3 & 4,1 \\
\hline 2. ДГ-67 & 9,3 & 8,4 & 8,1 & 8,6 & 7,5 & 6,2 & 6,6 & 6,8 \\
\hline 3. Бровадез $20+$ ДМСО & 9,2 & 6,6 & 8,3 & 8,0 & 5,7 & 2,3 & 5,0 & 4,3 \\
\hline 4. Без обробки (контроль) & 9,4 & 8,7 & 9,7 & 9,3 & 9,4 & 8,7 & 9,7 & 9,3 \\
\hline
\end{tabular}

Таблиця 4

Ураженість супереліти картоплі вірусами за впливу каскадної обробки посівів антивірусними препаратами

\begin{tabular}{|c|c|c|c|c|c|c|c|c|}
\hline \multirow[b]{3}{*}{ Препарат } & \multicolumn{8}{|c|}{ Віруси X, S, У в латентній формі, \% } \\
\hline & \multicolumn{4}{|c|}{$\begin{array}{l}\text { післядія } \\
\text { обробки } \\
\end{array}$} & \multicolumn{4}{|c|}{$\begin{array}{c}\text { накладання } \\
\text { обробки }\end{array}$} \\
\hline & 疋 & $\begin{array}{l}\text { ̊ి } \\
\text { ᄋ } \\
\text { N }\end{array}$ & 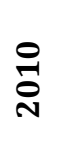 & 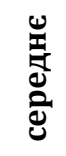 & 串 & ஓి & 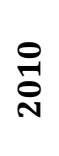 & 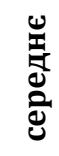 \\
\hline 1. Інтерферон & 5,2 & 0 & 0 & 1,7 & 0 & 0 & 0 & $\mathbf{0}$ \\
\hline 2. ДГ-67 & 0 & 0 & 0 & $\mathbf{0}$ & 0 & 0 & 0 & $\mathbf{0}$ \\
\hline 3. Бровадез $20+$ ДМСО & 2,6 & 5,0 & 5,0 & 1,2 & 2,6 & 5,0 & 5,0 & 1,2 \\
\hline $\begin{array}{l}\text { 4. Без обробки } \\
\text { (контроль) }\end{array}$ & 5,2 & 5,3 & 5,0 & 5,2 & 5,2 & 5,3 & 5,0 & 5,2 \\
\hline
\end{tabular}


Вірусів у латентній формі в досліджуваних варіантах було на 3,7-5,0 \% менше ніж у контролю (табл. 6).

Таблиця 5

Ураженість еліти картоплі вірусними хворобами за впливу каскадної обробки посівів антивірусними препаратами

\begin{tabular}{|c|c|c|c|c|c|c|c|c|c|}
\hline \multirow[b]{3}{*}{ Препарат } & \multicolumn{9}{|c|}{ Візуальні симптоми хвороб, \% } \\
\hline & \multicolumn{3}{|c|}{$\begin{array}{l}\text { післядія } \\
\text { післядії }\end{array}$} & \multicolumn{3}{|c|}{\begin{tabular}{|l|} 
післядія \\
обробки \\
\end{tabular}} & \multicolumn{3}{|c|}{ обробка } \\
\hline & 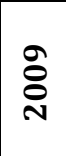 & $\underset{\text { 옹 }}{\stackrel{0}{\circ}}$ & & 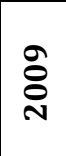 & $\begin{array}{l}\stackrel{0}{1} \\
\stackrel{\sim}{\text { N }}\end{array}$ & & 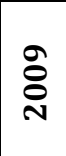 & $\underset{\text { 옹 }}{\stackrel{0}{\circ}}$ & 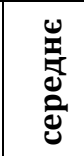 \\
\hline 1. Інтерферон & 6,2 & 11,9 & 9,0 & 5,0 & 11,2 & 8,1 & 5,2 & 7,8 & 6,5 \\
\hline 2. ДГ-67 & 8,6 & 15,8 & 12,2 & 8,3 & 14,5 & 11,4 & 6,6 & 11,8 & 9,2 \\
\hline $\begin{array}{l}\text { 3. Бровадез } 20+ \\
\text { ДМСО }\end{array}$ & 7,5 & 13,5 & 10,5 & 6,8 & 11,9 & 9,4 & 5,0 & 10,0 & 7,5 \\
\hline $\begin{array}{l}\text { 4. Без обробки } \\
\text { (контроль) }\end{array}$ & 8,1 & 16,0 & 12,0 & 8,1 & 16,0 & 12,0 & 8,1 & 16,0 & 12,0 \\
\hline
\end{tabular}

Еліта, отримана з обробленої методом накладання супереліти, була менше уражена вірусними хворобами ніж контроль на 3,9\% при використанні Інтерферону, на 0,6 \% - при використанні ДГ-67 та на 2,6\% - при використанні Бровадезу 20 з ДМСО. Результати візуальної оцінки стану посівів підтверджуються даними серологічної діагностики: післядія накладання обробок препаратами Інтерферон та Бровадез 20 з ДМСО призвела до меншої (на 12,5 та 11,3\%, відповідно), ніж у контролі, кількості вірусів в латентній формі. Еліта, отримана з послідовно оброблених суперсупереліти та супереліти препаратом ДГ-67, мала 10,0\% прихованих вірусів (контроль - 17,5\%).

У випадку послідовного накладання обробок впродовж всього процесу репродукування значне зменшення візуальних симптомів ураження вірусними хворобами відмічено в усіх досліджуваних варіантах. При використанні Інтерферону воно склало 5,5\%, ДГ-67 - 2,8, Бровадезу 20 з ДМСО - 4,5 \%. Зокрема діагностованих вірусів при використанні Інтерферону виявлено не було, тоді як при застосуванні ДГ-67 та Бровадезу 20 з ДМСО їх кількість складала лише 5,0 та 2,5 \%, відповідно (контроль - 17,5 \%). 
Таблиця 6

Ураженість еліти картоплі вірусами за впливу каскадної обробки посівів антивірусними препаратами

\begin{tabular}{|c|c|c|c|c|c|c|c|c|c|}
\hline \multirow[b]{3}{*}{ Препарат } & \multicolumn{9}{|c|}{ Віруси X, S, У в латентній формі, \% } \\
\hline & \multicolumn{3}{|c|}{$\begin{array}{l}\text { післядія } \\
\text { післядії }\end{array}$} & \multicolumn{3}{|c|}{$\begin{array}{l}\text { післядія } \\
\text { обробки }\end{array}$} & \multicolumn{3}{|c|}{ обробка } \\
\hline & ஓి & $\stackrel{\text { 융 }}{\text { O }}$ & 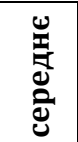 & 巳̊ & 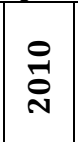 & 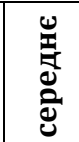 & ̊̊̊ి & 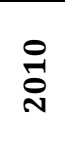 & 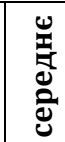 \\
\hline 1. Інтерферон & 15,0 & 10,0 & 12,5 & 5,0 & 5,0 & 5,0 & 0 & 0 & $\mathbf{0}$ \\
\hline 2. ДГ-67 & 15,0 & 12,5 & 13,8 & 10,0 & 10,0 & 10,0 & 5,0 & 5,0 & $\mathbf{5 , 0}$ \\
\hline 3. Бровадез $20+$ ДМСО & 15,0 & 10,0 & 12,5 & 5,0 & 7,5 & 6,2 & 0 & 5,0 & 2,5 \\
\hline 4. Без обробки (контроль) & 20,0 & 15,0 & 17,5 & 20,0 & 15,0 & 17,5 & 20,0 & 15,0 & 17,5 \\
\hline
\end{tabular}

Таким чином, слід відмітити явно виражену антивірусну дію Інтерферону на прояв вірусних хвороб картоплі, що підтверджується даними серологічного аналізу. Післядія каскадних обробок цим препаратом зберігається до еліти, а використання накладання обробок ще посилює його дію.

Препарат ДГ-67 лише в перший рік використання має помітний вплив на зменшення ураженості вірусами, в подальшому його дія, навіть за накладання обробок $\epsilon$ порівняно слабо вираженою, внаслідок чого візуальні симптоми ураження $є$ близькими до контролю.

Значний позитивний вплив, який спричиняє використання суміші Бровадезу 20 з ДМСО в першій рік, майже не зберігається в післядії, але накладання обробок свідчить про ефективність використання даної комбінації.

Проведеними впродовж 2016-2018 рр. дослідженнями також встановлено суттєве зменшення прояву вірусних хвороб за каскадної обробки посівів часнику озимого препаратами Інтерферон та ДГ-67. Польові досліди виконували за послідовного накладання досліджуваними препаратами. Отримані дані свідчать про зменшення симптомів ураження насіннєвих посівів часнику вірусними хворобами за концентрації Інтерферону 0,01-0,10 \%.

Так ураженість сорту Дюшес за використання Інтерферону зменшилась у 5,3 разів, сорту Мереф'янський білий - у 5,5 разів, що сприяло покращанню фітосанітарного стану посівів, зменшенню реінфекції, зростанню товарності та продуктивності рослин. Це також сприяло формуванню високих економічних показників виробництва насіннєвого матеріалу. 


\section{3. Вплив антивірусних препаратів}

на продуктивність рослин

Зменшення ураженості суперсупереліти вірусами призвело до відповідного зростання урожайності картоплі в усіх досліджуваних варіантах (табл. 7) на 5,2-11,0 т/га порівняно до контролю $(18,5$ т/га).

Таблиця 7

Урожайність суперсупереліти картоплі за впливу каскадної обробки посівів антивірусними препаратами

\begin{tabular}{|l|c|c|c|c|}
\hline \multirow{2}{*}{ Препарат } & \multicolumn{4}{|c|}{ Урожайність, т/га } \\
\cline { 2 - 5 } & $\mathbf{2 0 0 7}$ & $\mathbf{2 0 0 8}$ & $\mathbf{2 0 0 9}$ & середнє \\
\hline 1. Інтерферон & 44,7 & 29,3 & 14,6 & $\mathbf{2 9 , 5}$ \\
\hline 2. ДГ-67 & 38,7 & 27,2 & 10,9 & $\mathbf{2 5 , 6}$ \\
\hline 3. Бровадез 20 + ДМСО & 36,5 & 25,1 & 9,6 & $\mathbf{2 3 , 7}$ \\
\hline 4. Без обробки (контроль) & 25,4 & 22,6 & 7,4 & $\mathbf{1 8 , 5}$ \\
\hline НІР $_{05}$ & 1,17 & 0,37 & 0,62 & - \\
\hline
\end{tabular}

Зростання урожайності супереліти за впливу післядії антивірусних препаратів складає 1,9-3,9 т/га, тоді як накладання обробок обумовлює її збільшення на 2,0-6,5 т/га (табл. 8).

Таблиця 8

Урожайність супереліти картоплі за впливу каскадної обробки посівів антивірусними препаратами

\begin{tabular}{|c|c|c|c|c|c|c|c|c|}
\hline \multirow[b]{3}{*}{ Препарат } & \multicolumn{8}{|c|}{ Урожайність, т/га } \\
\hline & \multicolumn{4}{|c|}{$\begin{array}{l}\text { післядія } \\
\text { обробки }\end{array}$} & \multicolumn{4}{|c|}{$\begin{array}{c}\text { накладання } \\
\text { обробки }\end{array}$} \\
\hline & $\begin{array}{l}\infty \\
\stackrel{ᄋ}{0} \\
\text { ㄱ }\end{array}$ & ̊̊ & 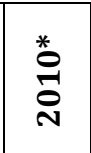 & 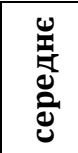 & 串 & 옹 & 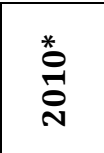 & 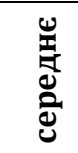 \\
\hline 1. Інтерферон & 24,9 & 12,3 & 0,61 & 12,6 & 29,3 & 13,2 & 0,64 & 14,4 \\
\hline 2. ДГ-67 & 24,3 & 10,9 & 0,57 & 11,9 & 25,3 & 12,7 & 0,60 & 12,9 \\
\hline 3. Бровадез 20 + ДМСО & 23,2 & 10,1 & 0,52 & 11,3 & 23,3 & 10,1 & 0,56 & 11,3 \\
\hline 4. Без обробки (контроль) & 19,8 & 9,6 & 0,48 & 10,0 & 19,8 & 9,6 & 0,48 & 10,0 \\
\hline $\mathrm{HIP}_{05}$ & 0,47 & 0,32 & 0,037 & - & 0,47 & 0,32 & 0,037 & - \\
\hline
\end{tabular}

* - дані не враховувались 
Найсуттєвішим є ефект від використання Інтерферону та ДГ-67. Зростання урожайності при застосування суміші Бровадезу 203 ДМСО в певній мірі лімітується наявністю вірусної інфекції в латентній формі.

Післядія Інтерферону зумовила зростання урожайності еліти на 2,4-2,7 т/га, тоді як Бровадезу 20 з ДМСО - лише на 0,7-1,1 т/га (табл. 9). Післядії препарату ДГ-67 виявлено не було.

Послідовне накладання обробок в процесі репродукування сприяло достовірному зростанню урожайності еліти на 3,3 т/га при використання Інтерферону, на 0,4 т/га при використанні ДГ-67 та на 2,7 т/га при використанні Бровадезу 20 з ДМСО.

Таким чином, найбільш виражену післядію на урожайність картоплі має Інтерферон, тоді як використання інших досліджуваних препаратів є більш доцільним при використанні послідовного накладання обробок в процесі репродукування (особливо у випадку з ДГ-67).

Таблиця 9

Урожайність еліти картоплі за впливу каскадної обробки посівів антивірусними препаратами

\begin{tabular}{|c|c|c|c|c|c|c|c|c|c|}
\hline \multirow[b]{3}{*}{ Препарат } & \multicolumn{9}{|c|}{ Урожайність, т/га } \\
\hline & \multicolumn{3}{|c|}{$\begin{array}{l}\text { післядія } \\
\text { післядії }\end{array}$} & \multicolumn{3}{|c|}{$\begin{array}{l}\text { післядія } \\
\text { обробки }\end{array}$} & \multicolumn{3}{|c|}{ обробка } \\
\hline & ஓి & $\begin{array}{l}\stackrel{*}{*} \\
\stackrel{-}{2} \\
\text { N }\end{array}$ & 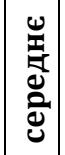 & $\begin{array}{l}\text { \&ి } \\
\text { ᄋ } \\
\text { N }\end{array}$ & 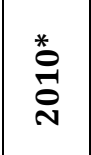 & & 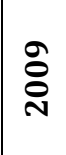 & $\begin{array}{l}\text { *0 } \\
\text { O- } \\
\text { ᄋ }\end{array}$ & 岂 \\
\hline 1. Інтерферон & 10,7 & 0,50 & 5,6 & 11,0 & 0,52 & 5,8 & 11,6 & 0,55 & 6,0 \\
\hline 2. ДГ-67 & 8,2 & 0,43 & 4,3 & 8,3 & 0,43 & 4,4 & 8,7 & 0,46 & 4,6 \\
\hline 3. Бровадез 20 + ДМСО & 9,0 & 0,43 & 4,7 & 9,4 & 0,46 & 4,9 & 11,0 & 0,48 & 5,7 \\
\hline 4. Без обробки (контроль) & 8,3 & 0,42 & 4,4 & 8,3 & 0,42 & 4,4 & 8,3 & 0,42 & 4,4 \\
\hline $\mathrm{HIP}_{05}$ & 0,3 & 0,038 & - & 0,3 & 0,038 & - & 0,3 & 0,038 & - \\
\hline
\end{tabular}

* - дані не враховувались

Зокрема застосування Інтерферону на часнику дозволяє суттєво збільшити його урожайність. Так у сорту Дюшес вона склала 4,8 т/га, що на 20,8\% вище контролю, а сорту Мерефянський білий $-4,3$ т/га, що на 23,2 \% перевищує контроль. 
Основними причинами зростання урожайності картоплі в варіантах досліду було зростання кількості бульб в кущі та збільшення їх середньої маси. При цьому суттєвих змін у співвідношенні фракцій бульб не спостерігалось.

Зростання кількості бульб кожної фракції відбувалось пропорційно їх частці в структурі урожаю. Особливу увагу в даному випадку слід приділити збільшенню кількості бульб насіннєвої фракції. Цей показник характеризує величину коефіцієнту розмноження насіннєвого матеріалу і $\epsilon$ основним критерієм процесу насінництва. Це також стосується інших рослин, що розмножують вегетативним шляхом.

Суттєве зростання кількості насіннєвих бульб суперсупереліти при використанні Інтерферону на 2,1 шт./кущ порівняно до контролю зумовило збільшення їх виходу на 86 тис. шт/га (табл. 10).

Таблиця 10

Насіннєва продуктивність суперсупереліти картоплі за впливу каскадної обробки посівів антивірусними препаратами

\begin{tabular}{|l|c|c|c|c|}
\hline \multirow{2}{*}{ Препарат } & \multicolumn{4}{c|}{ Насіннєва фракція, \% } \\
\cline { 2 - 5 } & $\mathbf{2 0 0 7}$ & $\mathbf{2 0 0 8}$ & $\mathbf{2 0 0 9}$ & середнє \\
\hline 1. Інтерферон & 51 & 89 & 82 & $\mathbf{7 4}$ \\
\hline 2. ДГ-67 & 50 & 92 & 85 & $\mathbf{7 6}$ \\
\hline 3. Бровадез 20 + ДМСО & 64 & 91 & 78 & $\mathbf{7 8}$ \\
\hline 4. Без обробки (контроль) & 63 & 94 & 71 & $\mathbf{7 6}$ \\
\hline
\end{tabular}

Зростання частки насіннєвих бульб при використанні ДГ-67 та Бровадезу 20 з ДМСО призвело до відповідного збільшення їх кількості на 56 і 59 тис. шт/га (табл. 11).

Таблиця 11

Вихід насіннєвих бульб суперсупереліти картоплі за впливу каскадної обробки посівів антивірусними препаратами

\begin{tabular}{|l|c|c|c|c|}
\hline \multirow{2}{*}{ Препарат } & \multicolumn{4}{|c|}{ Насіннєвих бульб, шт./кущ } \\
\cline { 2 - 5 } & $\mathbf{2 0 0 7}$ & $\mathbf{2 0 0 8}$ & $\mathbf{2 0 0 9}$ & середнє \\
\hline 1. Інтерферон & 6,3 & 7,9 & 7,7 & $\mathbf{7 , 3}$ \\
\hline 2. ДГ-67 & 6,0 & 7,6 & 6,1 & $\mathbf{6 , 6}$ \\
\hline 3. Бровадез 20 + ДМСО & 6,5 & 8,0 & 5,4 & $\mathbf{6 , 6}$ \\
\hline 4. Без обробки (контроль) & 4,6 & 7,2 & 3,8 & $\mathbf{5 , 2}$ \\
\hline НІР $_{05}$ & 0,30 & 0,46 & 0,40 & - \\
\hline
\end{tabular}


Суттєвого впливу досліджуваних препаратів на співвідношення бульб різних фракцій не відмічено. Зростання частки бульб насіннєвої фракції супереліти порівняно до суперсупереліти відмічено у всіх досліджуваних варіантах (табл. 12).

Таблиця 12

Насіннєва продуктивність супереліти картоплі за впливу каскадної обробки посівів антивірусними препаратами

\begin{tabular}{|c|c|c|c|c|c|c|c|c|}
\hline \multirow{3}{*}{ Препарат } & \multicolumn{8}{|c|}{ Насіннєва фракція, \% } \\
\hline & \multicolumn{4}{|c|}{$\begin{array}{l}\text { післядія } \\
\text { обробки }\end{array}$} & \multicolumn{4}{|c|}{$\begin{array}{c}\text { накладання } \\
\text { обробки }\end{array}$} \\
\hline & 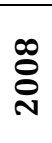 & ̊ి & $\begin{array}{l}\text { ㅇ } \\
\text { 온 }\end{array}$ & 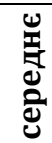 & $\begin{array}{l}\infty \\
\stackrel{\infty}{ᄋ} \\
\text { N }\end{array}$ & 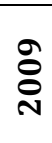 & $\begin{array}{l}\stackrel{0}{\sigma} \\
\text { 워 }\end{array}$ & 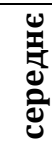 \\
\hline 1. Інтерферон & 90 & 74 & - & 82 & 89 & 73 & - & 81 \\
\hline 2. ДГ-67 & 89 & 74 & - & 82 & 90 & 78 & - & 84 \\
\hline 3. Бровадез $20+$ ДМСО & 88 & 74 & - & 81 & 92 & 73 & - & 82 \\
\hline 4. Без обробки (контроль) & 90 & 73 & - & 82 & 90 & 73 & - & 82 \\
\hline
\end{tabular}

Післядія досліджуваних препаратів дозволяє отримати додатково від 0,6 до 1,8 штук насіннєвих бульб супереліти на кущ (табл. 13). Це забезпечує їх надходження до 73 тис. шт./га за використання Інтерферону, до 82 тис. шт./га - за використання ДГ-67 та до 24 тис. шт./га - за використання Бровадезу 20 з ДМСО. У випадку застосування послідовного накладання обробок зростання кількості насіннєвих бульб складає 81, 73 та 34 тис. шт./га, відповідно.

Післядії у збільшенні частки бульб насіннєвої фракції еліти при обробці суперсупереліти по жодному варіанту виявлено не було (табл. 14). Незалежно від препарату та кратності обробки за послідовного репродукування вона складала 78-81 \%. Проте слід відмітити той факт, що даний показник на такому рівні спостерігається практично на всіх етапах розмноження. 
Таблиця 13

Вихід насіннєвих бульб супереліти картоплі за впливу каскадної обробки посівів антивірусними препаратами

\begin{tabular}{|c|c|c|c|c|c|c|c|c|}
\hline \multirow{3}{*}{ Препарат } & \multicolumn{8}{|c|}{ Насіннєвих бульб, шт./кущ } \\
\hline & \multicolumn{4}{|c|}{$\begin{array}{l}\text { післядія } \\
\text { обробки } \\
\end{array}$} & \multicolumn{4}{|c|}{$\begin{array}{c}\begin{array}{c}\text { накладання } \\
\text { обробки }\end{array} \\
\end{array}$} \\
\hline & 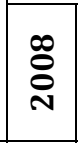 & ஓ̊̊ి & $\begin{array}{l}\stackrel{0}{0} \\
\text { 온 }\end{array}$ & 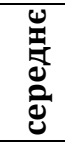 & 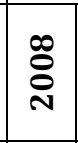 & ஓి & 음 & 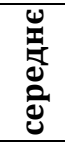 \\
\hline 1. Інтерферон & 7,9 & 7,2 & - & 7,6 & 8,1 & 7,6 & - & 7,8 \\
\hline 2. ДГ-67 & 7,6 & 6,0 & - & 7,8 & 8,0 & 7,3 & - & 7,6 \\
\hline 3. Бровадез $20+$ ДМСО & 7,3 & 5,6 & - & 6,4 & 7,2 & 6,2 & - & 6,7 \\
\hline $\begin{array}{l}\text { 4. Без обробки } \\
\text { (контроль) }\end{array}$ & 6,4 & 5,3 & - & 5,8 & 6,4 & 5,3 & - & 5,8 \\
\hline $\mathrm{HIP}_{05}$ & 0,37 & 0,36 & - & - & 0,37 & 0,36 & - & - \\
\hline
\end{tabular}

Таблиця 14

Насіннєва продуктивність еліти картоплі за впливу каскадної обробки посівів антивірусними препаратами

\begin{tabular}{|c|c|c|c|c|c|c|c|c|c|}
\hline \multirow[b]{3}{*}{ Препарат } & \multicolumn{9}{|c|}{ Насіннєва фракція, \% } \\
\hline & \multicolumn{3}{|c|}{$\begin{array}{l}\text { післядія } \\
\text { післядії }\end{array}$} & \multicolumn{3}{|c|}{$\begin{array}{l}\text { післядія } \\
\text { обробки }\end{array}$} & \multicolumn{3}{|c|}{ обробка } \\
\hline & 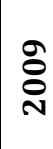 & $\begin{array}{l}\text { 옹 } \\
\text { O্ }\end{array}$ & 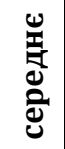 & ᄋ̊̀ి & $\stackrel{0}{\stackrel{0}{\circ}}$ & 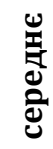 & ̨̊̊̊ & $\stackrel{\circ}{\stackrel{0}{0}}$ & \\
\hline 1. Інтерферон & 80 & - & 80 & 83 & - & 83 & 80 & - & 80 \\
\hline 2. ДГ-67 & 78 & - & 78 & 79 & - & 79 & 81 & - & 81 \\
\hline 3. Бровадез $20+$ ДМСО & 81 & - & 81 & 79 & - & 79 & 81 & - & 81 \\
\hline 4. Без обробки (контроль) & 81 & - & 81 & 81 & - & 81 & 81 & - & 81 \\
\hline
\end{tabular}

У випадку накладання обробок на супереліту значне зростання кількості насіннєвих бульб еліти відмічено лише при використанні Інтерферону - на 0,6 шт./кущ, що складає 24 тис. шт./га. У випадку послідовного накладання обробок впродовж всього репродукування суттєвий ріст кількості насіннєвих бульб еліти в кущі був відмічений за використання Інтерферону (на 0,6 шт./кущ) та Бровадезу 20 з ДМСО (на 0,8 шт./кущ). Це сприяє зростанню 
додаткових витрат, але дає змогу додатково отримати до 24-33 тис. шт. насіннєвих бульб еліти з 1 га (табл. 15).

Таблиця 15

Вихід насіннєвих бульб еліти картоплі за впливу каскадної обробки посівів антивірусними препаратами

\begin{tabular}{|c|c|c|c|c|c|c|c|c|c|}
\hline \multirow[b]{3}{*}{ Препарат } & \multicolumn{9}{|c|}{ Насіннєвих бульб, шт./кущ } \\
\hline & \multicolumn{3}{|c|}{$\begin{array}{c}\text { післядія } \\
\text { післядії }\end{array}$} & \multicolumn{3}{|c|}{$\begin{array}{l}\text { післядія } \\
\text { обробки }\end{array}$} & \multicolumn{3}{|c|}{ обробка } \\
\hline & O্̊ి & $\begin{array}{l}\stackrel{0}{1} \\
\stackrel{-}{0} \\
\text { N }\end{array}$ & 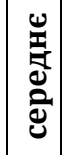 & ஓి & $\begin{array}{l}\stackrel{0}{1} \\
\stackrel{-}{0} \\
\text { N }\end{array}$ & 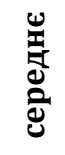 & $\begin{array}{l}\text { O̊ } \\
\text { O̊ } \\
\text { N }\end{array}$ & 옹 & لِّ \\
\hline 1. Інтерферон & 6,1 & - & 6,1 & 6,8 & - & 6,8 & 6,8 & - & 6,8 \\
\hline 2. ДГ-67 & 5,6 & - & 5,6 & 5,8 & - & 5,8 & 6,2 & - & 6,2 \\
\hline 3. Бровадез 20 + ДМСО & 6,0 & - & 6,0 & 6,2 & - & 6,2 & 7,0 & - & 7,0 \\
\hline 4. Без обробки (контроль) & 6,2 & - & 6,2 & 6,2 & - & 6,2 & 6,2 & - & 6,2 \\
\hline $\mathrm{HIP}_{05}$ & 0,28 & - & - & 0,28 & - & - & 0,28 & - & - \\
\hline
\end{tabular}

Таким чином післядія обробки суперсупереліти дозволяє додатково отримати насіннєвий матеріал еліти, якого вистачить ще на 64-147 га, залежно від препарату. У випадку послідовного накладання обробок отриманого додаткового насіннєвого матеріалу еліти вистачить на 123-200 га, але, якщо обробляти лише суперсупереліту та супереліту, накопичена післядія дозволяє додатково отримати елітних бульб картоплі ще на 87-200 га посівів.

В усіх випадках найвищі значення мають варіанти, де використовувалась каскадна обробка Інтерфероном, тому, враховуючи його значну післядію, доцільним $\epsilon$ одноразове його використання на суперсупереліті оздоровленого матеріалу картоплі.

При використанні препаратів ДГ-67 та Бровадезу 20 з ДМСО, післядія яких $\epsilon$ слабшою, доцільним $\epsilon$ одно- чи дворазове накладання обробок ними в процесі репродукування.

Не зважаючи на високу вартість препарату Інтерферон, затрати на виробництво еліти при його застосуванні зменшилися порівняно до контролю на 1138-2165 грн/га (табл. 16). 
Таблиця 16

Затрати на виробництво еліти оздоровленої картоплі при застосуванні каскадних обробок антивірусними препаратами, тис. грн/га

\begin{tabular}{|l|c|c|c|}
\hline \multirow{2}{*}{\multicolumn{1}{|c|}{ Препарат }} & \multicolumn{3}{|c|}{$\begin{array}{c}\text { Варіанти застосування препаратів } \\
\text { при репродукуванні картоплі }\end{array}$} \\
\cline { 2 - 4 } & $\begin{array}{c}\text { післядія } \\
\text { післядії }\end{array}$ & $\begin{array}{c}\text { післядія } \\
\text { накладання }\end{array}$ & накладання \\
\hline 1. Інтерферон & 19,176 & 18,886 & 19,913 \\
\hline 2. ДГ-67 & 18,977 & 18,713 & 19,169 \\
\hline 3. Бровадез 20 + ДМСО & 19,706 & 19,864 & 20,654 \\
\hline 4. Без обробки (контроль) & \multicolumn{3}{|c|}{21,051} \\
\hline
\end{tabular}

За рахунок зростання врожайності і насіннєвої продуктивності зменшення собівартості насіннєвого матеріалу склало 782-861 грн/т (табл. 17).

Таблиця 17

Собівартість еліти оздоровленої картоплі при застосуванні каскадних обробок антивірусними препаратами, грн/т

\begin{tabular}{|l|c|c|c|}
\hline \multirow{2}{*}{\multicolumn{1}{|c|}{ Препарат }} & \multicolumn{3}{|c|}{$\begin{array}{c}\text { Варіанти застосування препаратів } \\
\text { при репродукуванні картоплі }\end{array}$} \\
\cline { 2 - 4 } & $\begin{array}{c}\text { післядія } \\
\text { післядії }\end{array}$ & $\begin{array}{c}\text { післядія } \\
\text { накладанн } \\
\text { я }\end{array}$ & накладання \\
\hline 1. Інтерферон & 1886 & 1807 & 1807 \\
\hline 2. ДГ-67 & 2436 & 2372 & 2318 \\
\hline 3. Бровадез 20 + ДМСО & 2305 & 2224 & 1976 \\
\hline 4. Без обробки (контроль) & \multicolumn{3}{|c|}{2668} \\
\hline
\end{tabular}

Висока рентабельність виробництва еліти (на $62 \%$ вище контролю) зумовлена значною післядією даного препарату, що свідчить про можливість його застосування лише на суперсупереліті оздоровленої картоплі (табл. 18).

Зменшення затрат на виробництво еліти при застосуванні ДГ-67 складає 1882-2338 грн/га, але, внаслідок незначної їх окупності, собівартість картоплі зменшується лише на 232-350 грн/т. Саме тому зростання рентабельності виробництва еліти при застосуванні даного препарату є найменшим серед досліджуваних варіантів (на 14-23 \% порівняно до контролю) і $є$ найефективнішим 
при послідовному використанні каскадних обробок ДГ-67 впродовж всього процесу репродукування, що також пов'язано 3 відсутністю суттєвої його післядії.

Таблиця 18

Рентабельність виробництва еліти оздоровленої картоплі при застосуванні каскадних обробок антивірусними препаратами, грн/т

\begin{tabular}{|l|c|c|c|}
\hline \multirow{2}{*}{\multicolumn{1}{|c|}{ Препарат }} & \multicolumn{3}{|c|}{$\begin{array}{c}\text { Варіанти застосування препаратів } \\
\text { при репродукуванні картоплі }\end{array}$} \\
\cline { 2 - 4 } & $\begin{array}{c}\text { післядія } \\
\text { післядії }\end{array}$ & $\begin{array}{c}\text { післядія } \\
\text { накладання }\end{array}$ & накладання \\
\hline 1. Інтерферон & 112 & 121 & 121 \\
\hline 2. ДГ-67 & 64 & 69 & 73 \\
\hline 3. Бровадез 20 + ДМСО & 74 & 80 & 102 \\
\hline 4. Без обробки (контроль) & \multicolumn{3}{|c|}{} \\
\hline
\end{tabular}

При використанні Бровадезу 20 з ДМСО зменшення затрат на виробництво на 397-1345 грн/га та відповідне зменшення собівартості еліти на 363-692 грн/т призводить до зростання ії виробництва на 24-30 \% за рахунок післядії обробок та на $52 \%$ при послідовному їх застосуванні (рис 4.3). Але той факт, що послідовно оброблений насіннєвий матеріал $\epsilon$ в п'ять разів менше ураженим вірусними хворобами в латентній формі, свідчить саме про доцільність його застосування.

\section{Висновки}

1. Обробока досліджуваними препаратами оздоровленої картоплі методом накладання впродовж репродукування дозволяє зменшити візуальні симптоми вірусних захворювань суперсупереліти в 1,3-2,2 рази, супереліти - в 1,4-2,3, еліти - в 1,3-1,8 рази, що в більшості випадків супроводжується зменшенням інфікованості вірусами X, S та У в латентній формі. При використанні Інтерферону на суперсупереліті спостерігається його післядія на прояв симптомів вірусних хвороб, кількість яких у супереліти зменшується до 4,8 \% (контроль - 9,3 \%), а у еліти - до 9,0 \% (контроль - 12,0 \%).

2. Зростання урожайності суперсупереліти картоплі на 5,2-11,0 т/га спостерігається в усіх досліджуваних варіантах. Накладання обробок цими препаратами дозволяє отримати додатково 2,0-6,5 т/га супереліти та 0,4-3,3 т/га еліти. Післядія $\epsilon$ 
найсуттєвішою при застосуванні Інтерферону, дещо меншою при використанні Бровадезу 20 з ДМСО та незначною - за обробки ДГ-67.

3. Досліджені способи використання антивірусних препаратів дозволяють отримати додатковий насіннєвий матеріал картоплі, яким можна засадити до 200 га польових площ. Найефективнішим в даному випадку $є$ послідовне накладання каскадних обробок Інтерфероном в процесі репродукування (на суперсупереліті, супереліті та еліті), але, навіть застосування його лише на суперсупереліті дозволяє внаслідок післядії отримати додаткову кількість еліти на 147 га.

4. Досліджувані варіанти зумовлюють зростання рентабельності еліти на 14-71\%. Але, враховуючи суттєве зменшення ураженості вірусними хворобами, пов'язане з цим зростання урожайності i насіннєвої продуктивності, а також наявність післядії, більш доцільним $є$ використання каскадних обробок суперсупереліти Інтерфероном, що сприяє зменшенню затрат на виробництво еліти на 1875 грн/га, а ії собівартості - на 782 грн/т. Рівень рентабельності при цьому сягає 112 \% (контроль - 50 \%).

5. Використання Інтерферону призвело до зменшення симптомів ураження насіннєвих посівів часнику вірусними хворобами.). Так ураженість сорту Дюшес за даног препарату зменшилась у 5,3 разів, сорту Мереф'янський білий - у 5,5 разів. Запропонований спосіб дозволяє суттєво збільшити урожайність досліджуваних сортів - на 20,8 і 23,2 \%, відповідно.

\section{Список використаних джерел:}

1. Романова С. А., Рейфман В. Г., Реднева А. Н. Вакцинация картофеля слабопатогенным штаммом Х-вируса картофеля. Защита растений на Дальнем Востоке. 1989. С. 37-38.

2. Тринклер Ю. Г. О большом цикле развития картофельного растения. Физиология растений. 1960. № 6. С. 730-733.

3. Зыкин А. Г. Тли - переносчики вирусов картофеля. Л. : «Колос», 1970. 72 с.

4. Блоцкая Ж. В. Проблема вирусных и вирусоподобных заболеваний картофеля. Защита растений. Мн., Вып. XVIII. 1993. C. $34-40$.

5. Кононученко В. В. Наукове забезпечення галузі картоплярства. Картоплярство. К. : «Нора-принт», 2000. Вип. 30. C. 3-10. 
6. Вірусні хвороби картоплі / за ред. О. Й. Онищенка. К. : «Урожай», 1969. $142 \mathrm{c}$.

7. Линник Г. Н. Причины вырождения картофеля. Картофель. 1957. № 2. C. 26-27.

8. Сердюков А. Е., Писарев Б. А., Старцева Л. И. Семеноводство картофеля. М. : «Колос», 1984. 160 с.

9. Фаворов А. М. К истории вопроса о размножении картофеля семенами на Украине. Культура картофеля семенами. Горький, 1983. С. 7.

10. Рожалин Л. В. Агротехника семенного картофеля. Картофель. 1958. № 6. С. 4.

11. Немчин Ф. И. Изучение и проверка методов борьбы с вырождением картофеля в Молдавии. Maт. конф. по вопр. семеноводства картофеля. М. : Изд-во МСХ СССР, 1958. С. 14.

12. Фаворов А. М. Насінництво картоплі в Українській РСР. Харків, 1946. $68 \mathrm{c}$.

13. Лысенко Т. Д. Заготовить больше верхушек картофеля. М. : Огизсельхозгиз, 1947. 16 с.

14. Чесноков Н. С. Причины вырождения картофеля на юге и меры борьбы с ним. Мат. конф. по семеноводству картофеля. Л. : Изд-во ВАСХНИЛ, 1958. С. 61-63.

15. Соколенко Н. Ф. Выращивание здорового семенного картофеля на юге. Науч. тр. селекционно-генетического ин-та им. Т.Д. Лысенко. Одесса, 1962. С. 14-22.

16. Балашев Н. Н. Семеноводство картофеля на юге СССР. М. : Сельхозиздат, 1963. 172 с.

17. Бондарев М. Т. Борьба с вырождением картофеля на юге СССР при культуре его ростками. М. : Росиздат, 1938. 276 с.

18. Фаворов А. М., Котов А Ф. Летняя посадка картофеля. М. : Госсельхозиздат, 1952.320 с.

19. Муш Н. Н. О взаимодействии гетеротрофного и автотрофного питания в онтогенезе картофеля. Физиология растений. 1961. Т. 8, вып. 2. С. 183-187.

20. Максимович М. М. Семеноводство картофеля. М. : Сельхозгиз, 1951. 164 c.

21. Дунин М. С. Вирусные болезни сельскохозяйственных растений. М. : Сельхозиздат, 1937.107 с.

22. Дунин М. С. О некоторых методах получения и применения антивозбудительных сывороток в фитопатологии и энтомологии. Вестник с.-х. науки. 1958. № 3. С. 31-33. 
23. Рыжков В. Л. Фитопатогенные вирусы. М. : Изд-во АН СССР, 1946. $226 \mathrm{c}$.

24. Сухов К. С. Общая вирусология. М. : Высшая школа, 1965. 136 с.

25. Сухов К. С. Проблемы общей и сельскохозяйственной вирусологии. Защита растений от вредителей и болезней. 1960. № 1. С. 19-24.

26. Букасов С. М., Камераз А. Я. Основы селекции картофеля. М. : Сельхозгиз, 1959. 528 с.

27. Фом'юк М. К. Розвиток готики картоплі залежно від умов вирощування. Питання насіннищтва картоплі та боротьби з їі виродженням. К. : Вид-во УАСГН, 1960. С. 60-68.

28. Подгаєцький А. А. Створення вихідного матеріалу, стійкого проти вірусів і вірусних хвороб. Картоплярство. К. : «Нора-принт», 2000. Вип. 30. С. $19-26$.

29. Чесноков П. Г. Болезни вырождения картофеля в СССР. М. - Л. : Изд-во с.-х. лит-ры, журналов и плакатов, 1961. 320 с.

30. Картопля / за ред. В. В. Кононученка, М. Я. Молоцького. Біла Церква. 2002. Т. 1.536 с.

31. Башкин Е. Л. О вырождении и семеноводстве картофеля. Картофель и овощи. 1961. № 3. С. 14-15.

32. Башкин Е. Л. Вырождение картофеля и меры борьбы с ним. М. : «Наука», 1966. С. 14-15.

33. Бордукова М. В. Отбирать растения новыми методами. Картофель и овощи. 1961. № 1. С. 17-19.

34. Рейфман В. Г. Вирусные болезни картофеля и их распространение на Дальнем Востоке. Вирусные болезни картофеля. М. : «Наука», 1966. С. 85-93.

35. Фомюк М. К. О готике картофеля. Борьба с болезнями с.-х. растений. К. : Изд-во АН УССР, 1953. С. 46-48.

36. Сухов К. С., Развязкина Г. М. Биология вирусов и вирусные болезни растений. М. : Наука, 1955. 236 с.

37. Рожалин Л. В. Исследование вырождения семенного картофеля : отчёт н.-и. института картофельного хозяйства за 1941-1944 2.2. М. : Сельхозгиз, 1947. 36 с.

38. Дунин М. С. Вырождение и вирусные заболевания картофеля. Защита растений от вредителей и болезней. 1956. № 1. С. 35-37.

39. Абрамов И. Н. Болезни картофеля на Дальнем Востоке. Хабаровск : книжное изд-во, 1953. 221 с.

40. Польова стійкість сортів картоплі проти вірусних хвороб в умовах південного Полісся України / О. І. Терещенко, 3. В. Родіонова та ін. К. : Урожай, 1974. Вып. 5. С. 11-13. 
41. Сокол П. Ф. Зберігання картоплі та овочів. К. : «Урожай», 1968. 252 c.

42. Удовицкий А. С. Безвирусное картофелеводство и иммунитет. Интенсификация производства картофеля на Дальнем Востоке. Новосибирск, 1987. С. 42-47.

43. Герасимов С. Б., Леонтьева Ю. А. К вопросу о безвирусном семеноводстве картофеля. Современные проблемы семеноводства картофеля на безвирусной основе. Владивосток, 1985. С. 68-72.

44. Мамчур А. Е., Дмитрук Ю. А., Погорилько Н. А. К вопросу о вырождении картофеля и изменчивости при культивировании in vitro. Картоплярство. К. : «Урожай», 1998. Вип. 28. С. 90-94.

45. Власов Ю. А., Ларина Э. И. Сельскохозяйственная вирусология. М. : Колос, 1982. 239 с.

46. Мэттьюз Р. Вирусы растений. М. : Мир, 1973. 600 с.

47. Вирусные болезни и семеноводство картофеля / пер. с англ. Т. Н. Теплоуховой и Э. В. Трускинова, под ред. Ю. И. Власова. М. : Колос, 1976. 288 с.

48. Можаева К. А., Васильева Т. Я., Кастальева Т. Б. Вироид веретеновидности клубней картофеля передается через корневую систему. Картофель и овощи, 1987. № 2. С. 28.

49. Адамов И. И., Матюшенко А. Л. Вирусы и урожайность картофеля. Картофелеводство. Мн. 1985. Вып. 6. С. 61-66.

50. Починок В. Я. Залежність урожайності картоплі від ступеня ураження їі вірусними хворобами. Картоплярство. К. : «Урожай», 1987. Вип.18. С. 27-33.

51. Кучко А. А., Мицько В. М. Фізіологічні основи формування врожаю і якості картоплі. К. : «Довіра», 1997. 142 с.

52. Физиология картофеля / под ред. Б. А. Рубина. М., «Колос», 1979. $294 \mathrm{c.}$

53. Динер Т. О. Вироиды. Перспективы биохимических исследований. М. : Мир, 1987. С. 151-160.

54. Ильина М. Г. Аминокислоты и амиды в семенных клубнях картофеля в связи с их продуктивными качествами. Агрохимия, 1975. № 2. С. 77-82.

55. Цоглин Л. Н. Фотосинтетический аппарат растений картофеля при длительном действии вирусной инфекции. Физиология растений. 1987. Т. 34, № 6. С. 1403-1412.

56. Берштейн Б. И., Леонтьева Ю. А., Оканенко А. С. Влияние различных типов вырождения картофеля на содержание аминокислот в клубнях. Докл. АН СССР, 1960. Т. 134, № 4. С. 79-85. 
57. Смит К. Вирусные болезни растений. М. : Изд-во иностран. лит-ры, 1960.520 с.

58. Дубовик В. І. Вплив насіннєвого матеріалу картоплі на його продуктивність при репродукуванні. Картоплярство. К. : «Норапринт», 2000. Вип. 30. С. 130-135.

59. Педько О. І. Вплив синтетичних хімічних препаратів на вірусну інфекцію при розмноженні оздоровленого матеріалу у полі. Картоплярство. К. : «Аграрна наука», 1994. Вип. 25. С. 53-56.

60. Герасимов С. Б., Леонтьева Ю. А. К вопросу о безвирусном семеноводстве картофеля. Современные проблемы семеноводства картофеля на безвирусной основе. Владивосток, 1985. С. 56-59.

61. Рейфман В. Г., Гнутова Р. В., Романова С. А. Физиолого-биохимические свойства вирусов, поражающих картофель и приёмы оздоровления семенного материала на Дальнем Востоке. Сельскохозяйственная биология. 1996. № 3. С. 93-106.

62. Розенберг В. Р. Факторы, влияющие на эффективность оздоровления картофеля от мозаичных вирусов методом верхушечной меристемы. Сб. реф. НИР. 1981. № 4. С. 5.

63. Демкович Я. Б. Продуктивність насіннєвої картоплі залежно від виду вихідного матеріалу та способу його формування. Картоплярство. К. : «Аграрна наука», 1998. Вип. 28. С. 171-173.

64. Агур М. О. О повторной вирусной инфекции семенного картофеля, оздоровленного методом апикальной меристемы. Селекция и семеноводство. 1992. № 4-5. С. 59-64.

65. Амбросов А. Л. Вирусные болезни картофеля и методы выращивания здоровых семенных клубней. Минск : Урожай, 1964. 198 c.

66. Різник В. С. Оздоровлення картоплі: проблеми і перспективи. Картоплярство. К. : «Аграрна наука», 1997. Вип. 27. С. 23-24.

67. Гребенщикова С. Условия, влияющие на поражаемость картофеля вирусами. Картофель и овощи. 1975. № 7. С. 38.

68. Куприянов Д. Н. Накопление вирусной инфекции в зависимости от условий выращивания и качества исходного материала. Селекция и семеноводство картофеля. М. 1978. Вып 31. С. 94-98.

69. Майщук 3. М. Мікроклональне розмноження картоплі in vitro : проблеми та перспективи у первинному насінництві. Kapmonлярство. К. : «Аграрна наука», 1997. Вип.27. С. 182-189.

70. Майщук 3. М. Влияние культуры меристемы и термотерапии на изменчивость признаков и семенные качества картофеля на безвирусной основе. Владивосток, 1985. 38 с. 
71. Букасов С. М., Шарина Н. Е. История картофеля. М. : Сельхозгиз, 1938. 37 с.

72. Майщук 3. М. Ефективність клонових доборів у селекції картоплі. Картоплярство. К. : «Аграрна наука», 1993. Вип. 24. С. 14-17.

73. Дубинин Н. П. Общая генетика. М. : Наука, 1986. 559 с.

74. Sward R., Hallan N. Changes in fine structure of the potato meristems following heat treatment for virus eradication. Austral J. Bot., 1976. № 5. p.597-605.

75. Кучумов А. П., Князев В. А. Культура тканей и клеток в селекции и семеноводстве картофеля. М. : ВНИИТЭИИСХ ВАСХНИЛ, 1980. $48 \mathrm{c}$.

76. Владимиров М. В. Усовершенствование системы и методов семеноводства. Сб. реф. НИР. 1987. № 8. С. 30.

77. Глущенко И. Е., Савинская Н. В. Клоновая селекция картофеля. М., 1956. 88 с.

78. Демкович Я. Б., Верменко Ю. Я. Ураженість насіннєвої картоплі вірусами в процесі репродукування залежно від різновиду вихідного матеріалу. Картоплярство. К. : «Нора-принт», 2000. Вип. 30. C. 118-123.

79. Гребенюк М. Т., Жигайло И. И. Устойчивость картофеля к вирусным заболеваниям. Защита растений. 1975. № 5. С. 54.

80. Верменко Ю. Я. Вплив умов вирощування насіннєвого матеріалу на зараженість картоплі вірусами X, M, S. Картоплярство. К. : «Урожай», 1976. Вип. 7. С. 25-26.

81. Ольшевська 3. А. Продуктивність насіннєвої картоплі залежно від строків її збирання. Картоплярство. К. : «Урожай», 1978. Вип. 9. С. $49-54$.

82. Свертока В. Е., Тищенко О. Г. Продуктивність оздоровленої картоплі залежно від умов вирощування. Картоплярство. К.: «Урожай», 1982. Вип. 13. С. 44-47.

83. Линдерманис Я. М. Разработка мероприятий предохранения семенного картофеля от заражения вирусами. Сб. реф. НИР. 1974. № 13. С. 37.

84. Картопля - другий хліб / упоряд. та заг. ред. П. С. Теслюка. К. : «Довіра», 1985. Вип. 1. 281 с.

85. Амбросов А. Л., Соболь Я. В. Влияние температуры хранения клубней картофеля на накопление в них вирусов. Картофелеводство. Мн. 1974. Вып. 2. С. 140.

86. Зейрук Т. В. Способы повышения эффективности оздоровленного картофеля и изменчивость растений из верхушечных 
меристем при использовании физиологически активных веществ. Сб. реф. НИР. 1986. № 11. С. 11.

87. Постников Д. А. Защита от вирусных болезней и поддержание высокой продуктивности оздоровленного материала картофеля с помощью ингибитора вирусов и регуляторов роста. Сб. реф. НИР и ОКР. 1990. № 15. С. 34 .

88. Гайдук П. П. Изучение антивирусного действия некоторых химических соединений с целью защиты семенного картофеля от вирусных болезней. Сб. реф. НИР. 1983. № 15-16. С. 23.

89. Изучение приёмов оздоровления семенного картофеля (обработка семян и ботвы химическими препаратами, подбор оптимальных сроков уборки ботвы) сорта Приекульский ранний. Сб. реф. НИР. 1980. № 27. С. 7.

90.Блоцкая Ж. В. Проблема вирусных и вирусоподобных заболеваний картофеля. Защита растений : сб. науч. тр. Бел. НИИ защиты растений. Мн. : 1995. Вып. XVIII. С.34-40.

91. Павлов М. А. Изучение химического способа задержки прорастания клубней семенного картофеля при хранении. Сб. реф. НИР. 1973. № 5. С. 25.

92. Шмыгля В. А., Постников Д. А., Кинякин Н. Ф. Применение ингибитора вирусов ДГТ и регуляторов роста. Химизация сельского хозяйства. 1991. № 5. С. 36-42. 